\title{
SOFRIMENTO, TEMPO, TESTEMUNHO: EXPRESSÕES DA VIOLÊNCIA EM UM CONFLITO DE TERRAS
}

\author{
Dibe Ayoub* \\ Museu Nacional/Universidade Federal do Rio de Janeiro - Brasil
}

Resumo: Tendo como foco experiências femininas ao longo de um conflito de terras no Paraná, pretendo discutir noções de "sofrimento", assim como analisar aquilo que pode ou não ser comunicado sobre as situações de violência vividas ou conhecidas na luta pelo território. A partir das histórias de Joaquina e de Francisca, que viveram experiências trágicas durante o conflito, a noção de "sofrimento" surge acompanhada de diferentes perspectivas temporais, as quais por sua vez apontam para distintas percepções do sofrer. Além disso, seus relatos inspiram questionamentos sobre as possibilidades de produção de testemunhos sobre as violências vividas, e sobre em que medida, naquele contexto, é possivel denunciar as agressões sofridas. Por fim, busco compreender como os posseiros que viveram a luta por terras elaboram suas falas sobre as mortes que ocorreram no conflito, que eventos buscam destacar e silenciar.

Palavras-chave: conflito, sofrimento, testemunho, violência.

Abstract: By focusing on women's experiences over a land dispute in the State of Paraná, I intend to discuss notions of "suffering", as well as analyze what may or may not be reported on the violence experienced or known in the fight for territory. From the stories of Joaquina and Francisca, who lived tragic experiences during the conflict, the notion of "suffering" appears accompanied by different temporal perspectives, which in turn point to distinct perceptions of suffer. In addition, their stories inspire questions about the possibilities of production of testimonies of the violence lived, and about to what extent, in that context, it is possible to denounce the assaults suffered. Finally, I seek to understand how the "posseiros" who lived the struggle for land tell stories about the deaths that occurred during the conflict, which events they highlight and which ones they silence.

Keywords: conflict, suffering, testimonial, violence.

* Doutoranda em Antropologia Social.

Horizontes Antropológicos, Porto Alegre, ano 20, n. 42, p. 107-131, jul./dez. 2014 http://dx.doi.org/10.1590/S0104-71832014000200005 


\section{Introducão}

O presente artigo parte de experiências de violência vividas por mulheres ao longo de um conflito de terras no município de Pinhão, interior do Paraná. ${ }^{1}$ Ao concentrar-me nas narrativas que elas produzem sobre eventos disruptivos ocorridos em embates com uma empresa madeireira, busco discutir como relacionam noções de tempo à ideia de "sofrimento", e observo como os atos de fala qualificam as pessoas que contam suas histórias de vida e o mundo social em que vivem. Por outro lado, as narrativas acerca do conflito, e das agressões que o constituem, introduzem-nos a uma série de silêncios e de ausências de escuta sobre essas situações. Enquanto algo que é socialmente produzido, o silêncio está imbricado aos modos com que a violência e suas possíveis retaliações e desencadeamentos são compreendidos pelas comunidades rurais pinhãoenses que vivem a luta por terras.

Localizado em uma região de florestas de araucária, Pinhão entrou para o mapa da exploração madeireira no Paraná na década de 1940. A maior empresa desse ramo no município foi a Indústrias João José Zattar S/A, localmente conhecida como "Zattar". O conflito girou em torno das negociações que a madeireira e seus funcionários realizavam nas terras da zona rural de Pinhão, e da apropriação de áreas onde havia moradores, os quais, na maioria das vezes, não possuíam os documentos dos terrenos em que viviam.

O "sistema faxinal" (Chang, 1988; Porto, 2013b; Souza, 2010), que caracterizou historicamente a ocupação das áreas de matas de araucárias no município, implicava uma divisão espacial em que as florestas eram utilizadas para a criação de gado à solta, em áreas de uso comum, e para o extrativismo de erva-mate e de pinhão. As lavouras, por sua vez, eram feitas em áreas particulares e distantes das de mata, geralmente perto de campos, ou em encostas de serras e beiras de rios. ${ }^{2}$ Enquanto nos espaços de uso comum dessa população

\footnotetext{
1 O trabalho de campo em Pinhão iniciou-se em 2009 e encontra-se em andamento. A pesquisa fundamentou minha dissertação de mestrado (Ayoub, 2011), e fez parte do Projeto Memórias dos Povos do Campo do Paraná, viabilizado pelo Instituto de Terras, Cartografia e Geociências do Estado do Paraná (ITCG) e financiado pelo Ministério da Cultura (MinC). Desde 2013, o trabalho recebe financiamento do Edital de Auxílio à Pesquisa PPGAS/MN/UFRJ e Capes.

2 Esse sistema de ocupação e classificação do território se modificou através dos anos, de modo que na maior parte do município não existe mais a criação de animais à solta. Com a inserção de novos agentes
} 
a madeireira documentou uma vasta porção de terras em seu nome, nos lugares onde havia pequenas propriedades os agentes da empresa buscavam persuadir as pessoas a venderem-nas. Ademais, os empresários da Zattar expandiram seus interesses aos campos e às serras, nos quais passaram a criar gado.

Nas terras que adquiria, a madeireira colocava homens de armas, cuja função era convencer os moradores a assinarem "contratos de arrendo" com a firma, e vigiar os terrenos sob domínio dela. Através desses "contratos", as pessoas reconheciam a propriedade da madeireira sobre o território, e passavam a ser "moradoras" das áreas da empresa. Com isso, sujeitavam-se a restrições sobre suas atividades econômicas: deveriam fazer roça somente nos períodos indicados pela firma, não poderiam retirar pinhão ou extrair erva-mate, e eram proibidas de cortar árvores. Tinham ainda que pagar aos homens da empresa $30 \%$ de tudo que colhiam. Esses homens, que vigiavam as terras adquiridas pela madeireira, são reconhecidos no município como "guardas", "jagunços" e "pistoleiros", categorias que envolvem ideais morais, assim como critérios de aproximação e de distanciamento em relação a esses agentes (Ayoub, 2011, 2013). Enquanto "guarda" é um substantivo que indica respeito e ameniza os abusos cometidos por esses homens, "jagunço" é um termo pejorativo, que invoca a agressividade daquele que exercia essa função. "Pistoleiro", por sua vez, é um termo que enfatiza a "ruindade" dos homens armados da empresa, que poderiam ser pagos para matar em nome de outras pessoas.

Moradores das comunidades que vigiavam, os "jagunços" faziam parte das redes de parentesco e de trocas existentes nessas vizinhanças. Mesmo os homens de armas que vinham "de fora" de Pinhão construíam vínculos com os "moradores" das áreas da empresa. Ademais, o município é local e regionalmente tido como lugar com "fama de valente", onde antigamente todos andavam armados, onde há homens "ruins", que gostam de "brigar", e essas

nessas terras - como a própria madeireira e pessoas "de fora", que não estavam habituadas ao "sistema faxinal" -, as propriedades passaram a ser cercadas, e os animais criados em seu interior. Mesmo assim, o termo "faxinal" permanece sendo localmente acionado para representar o ambiente de matas. A territorialidade e o modo de vida faxinalense são reconhecidos pelo Estado do Paraná desde 2007, segundo a lei $n^{\circ} 15.673$ (Paraná, 2007). No ano de 2013, por intermédio dessa legislação, dois faxinais de Pinhão foram constituídos em Áreas Especiais de Uso Regulamentado (Aresur).

Horizontes Antropológicos, Porto Alegre, ano 20, n. 42, p. 107-131, jul./dez. 2014 
"brigas" frequentemente acarretam mortes e "vinganças". ${ }^{4}$ Assim, as pessoas que vivem o conflito com a madeireira compartilham valores agonísticos, e fazem parte de coletividades (famílias, comunidades, vizinhanças) para as quais as reputações encontram-se sempre em risco, e os desentendimentos se tornam questão pública (Campbell, 1971). No sentido de "sociabilidade agonística", então, o conflito é "um pressuposto das relações e foco de estruturação social" (Comerford, 2003, p. 68). As percepções que os sujeitos possuem acerca dos embates, assassinatos e dos agentes das agressões ocorridas ao longo da luta por terras levam em conta uma ética sobre os usos de força armada e sobre modos de atuação em situações de conflito.

Analiso aqui as maneiras com que pessoas que se identificam como "posseiras", integrantes de um movimento social de luta por terras contrário à madeireira, compreendem e vivenciam o conflito e suas violências. ${ }^{5}$ Nas duas primeiras seções do texto discuto as histórias das senhoras Joaquina e Francisca, tal como contadas por elas mesmas, sobre as experiências de violência que viveram no conflito de terras. Enquanto memórias, as narrativas dessas senhoras podem também ser vistas como "prática moral" (Lambek, 1996, p. 248),

\footnotetext{
3 As "brigas" costumam ser propagadas por homens, por vezes apenas uma dupla deles, por vezes por uma coletividade, e ocorrem em espaços públicos: bares, bailes, festas. São fruto de atos concebidos como ofensivos ou provocativos, e seu desenrolar envolve o acionamento de lutas corporais, pedras, paus, facões, revólveres, enfim, qualquer objeto que possa ser utilizado como arma para ferir o outro. Pode acarretar em sérios ferimentos para os envolvidos, ou até mesmo a morte de um deles.

4 "Vingança", enquanto categoria nativa de conflito, consiste em situações em que sujeitos que tiveram parentes ou amigos mortos se unem para punir os culpados por suas perdas. Dessa maneira, tendem a ser organizadas por uma coletividade, e estão vinculadas a uma concepção particular de justiça e de resolução de problemas. A "vingança" possui o caráter de obrigação, ainda que os sujeitos sempre salientem o abrandamento dessa obrigatoriedade no tempo presente. Mesmo assim, é comum ouvir casos de pessoas que atuam com violência tanto no sentido da troca de ofensas quanto para garantirem que sejam vistas com respeito por seus vizinhos, que por sua vez reconhecem os perigos de se mexer com um sujeito "vingativo".

5 Incentivado por freis e irmãs da Igreja Católica, assim como por militantes de esquerda, sindicalistas e organizações não governamentais, o Movimento de Posseiros é instituído no início dos anos 1990, englobando pessoas que viviam o conflito de terras com a madeireira. Ele é organizado após a formação de um órgão em defesa dos trabalhadores rurais, a Associação das Famílias dos Trabalhadores Rurais de Pinhão (Afatrup), inaugurada em 1987. Apesar da heterogeneidade interna do movimento, o termo "posseiro" traduz aquilo que os sujeitos tinham em comum: eles viviam em terras de posse, que estavam sob o domínio da madeireira Zattar. Nos anos 2000, novos movimentos sociais de luta pela terra se consolidaram em Pinhão, dentre os quais o Movimento dos Trabalhadores Rurais Sem-Terra (MST), o Movimento dos Pequenos Agricultores (MPA), e a Articulação Puxirão dos Povos Faxinalenses (APF). Todos esses movimentos sociais se relacionam entre si, tanto em termos dos deslocamentos e vínculos entre seus membros quanto em termos de estratégias políticas de atuação.
}

Horizontes Antropológicos, Porto Alegre, ano 20, n. 42, p. 107-131, jul./dez. 2014 
através da qual expressam a dimensão temporal de suas experiências de vida, os seus compromissos e suas identificações sociais.

Além disso, as falas de Joaquina e de Francisca acionam um repertório de julgamentos e práticas que dizem respeito ao modo com que elas conduzem uma certa "elaboração do trabalho ético" sobre si mesmas, a fim de se tornarem sujeitos morais de suas condutas (Foucault, 2010). Seus discursos são marcados pela organização social da vida, já que, através da memória, o indivíduo define seu lugar social e suas relações com os outros (Pollak, 1989). Os princípios dessas relações também constituem as narrativas, influenciando os modos com que se fala sobre determinados assuntos.

Enquanto a narrativa de Joaquina se estrutura a partir da ideia de "sofrimento" como destino moral que a acompanha por toda a vida, em Francisca o "sofrimento" surge em relação ao "tempo do Zattar", e a eventos de violência específicos. Assim, a experiência e sentimento de sofrer aparecem vinculados a certas ideias de temporalidade. Construída segundo determinadas noções de ordem e valores, a memória diz respeito ao contexto em que se insere o sujeito que a conta, contexto que não é somente aquele do momento presente, mas que tem a ver com a continuidade de determinadas relações, ao longo de um período de tempo. Assim, a memória não é fixa, atemporal, mas sim um processo construído no e com o tempo (Fabian, 1998). As narrativas constroem paradigmas cronológicos, através da seleção de eventos cujos significados são identificados na rede de acontecimentos aos quais se conectam. Disso decorre que um evento não existe como realidade objetiva, mas é construído como tal pela rede de relações em que se insere (Portelli, 1991).

Ambas as mulheres passaram por situações drásticas em suas relações com a empresa: Joaquina teve sua casa queimada, e Francisca teve o marido morto e a casa alvejada de tiros. Seus relatos nos conduzem a julgamentos, ideais de justiça e de resolução de tensões, que indicam que o conflito é compreendido e narrado a partir das relações vividas ao longo do período de embates com a madeireira, e de concepções morais que constituem e são constituídas por essas relações.

Apesar de as serrarias terem sido fechadas, e de os "jagunços" não mais inviabilizarem a vida dos posseiros, a madeireira ainda detém muitas terras no município, as quais tenta negociar com o Instituto Nacional de Colonização e Reforma Agrária (Incra), que deverá regularizar a situação fundiária dos 
moradores dessas áreas. ${ }^{6}$ Muitas pessoas ainda sofrem com as reintegrações de posse e com a possibilidade de serem expulsas dos lugares onde vivem. E há também aqueles que, embora não sofram com esses processos jurídicos, revelam-se temerosos de que "o Zattar" volte.

Se "sofrimento" é uma categoria frequente nos discursos, "violência" aparece muito pouco, e geralmente marca distanciamentos e a não identificação. Nesse sentido, o "jagunço" e o "pistoleiro" podem ser associados à "violência". Porém, as narrativas sobre o conflito fundiário combinam diversas formas de agressão, como aquelas internas à constituição das famílias, aquelas que dizem respeito à história dos grupos e ao povoamento da região, as referentes às disputas de terras entre vizinhos e, finalmente, entre camponeses e madeireira. Ou seja, a violência permeia a própria construção da vida, não enquanto um lugar único e bem moldado, mas como algo que perpassa diversas formas de relações e agrega valores e sentimentos a pessoas e situações.

Ao rememorarem suas experiências na luta por terras, posseiras e posseiros também abordam os limites das possibilidades de fala e de escuta sobre as situações vividas. Permeados por sentimentos, como o "medo" e o próprio "sofrimento", os discursos aqui analisados podem ser tomados como "emocionais" (Lutz; Abu-Lughod, 1990). Na medida em que envolvem o acionamento de disposições cultivadas ao longo da vida, a partir de códigos sociais, as emoções são experiência incorporada, e podem servir de idioma para comunicar conflitos e agressões. Mas há violências que são incomunicáveis segundo a moralidade da vida cotidiana. De acordo com Das (2007), é o amálgama entre poder, contexto e sentimentos que constrange as vozes, constituindo mais do que o silenciamento de certos atos, mas a real impossibilidade de se falar deles. Indicativo dos limites da experiência, o silêncio tem a ver com a gestão da memória e com a possibilidade de comunicá-la (Pollak, 1990).

Nos casos analisados a seguir, distintos silenciamentos são colocados em questão. O primeiro se refere ao testemunho dos eventos de violência, ou seja, àquilo que pode ser dito sobre o que se sabe deles. Nesses casos, é a ameaça

\footnotetext{
6 Durante a década de 1990, a madeireira passou por uma série de problemas econômicos e pela intensificação do conflito de terras, que contribuíram para o fechamento das serrarias em Pinhão. Aos poucos, os administradores da empresa deixaram de lado a política de vigilância da vida cotidiana dos posseiros, e passaram a exercer sua pressão sobre as terras por meio de processos jurídicos. Ainda que os "guardas" não mais atuem como antigamente, alguns deles permanecem vivendo e cuidando de territórios da firma, ou ainda moram no município.
}

Horizontes Antropológicos, Porto Alegre, ano 20, n. 42, p. 107-131, jul./dez. 2014 
de que o agressor possa fazer algo contra a pessoa que tem conhecimento dos atos por ele cometidos, ou contra quem busca a reparação legal de algum dano sofrido, que permeia o silêncio. $\mathrm{O}$ segundo tem a ver com a ultrapassagem de fronteiras do que é moralmente aceitável e compreensível em termos de agressão física. É assim que buscarei discorrer sobre as mortes de que não se fala e, em contraposição, sobre aquelas de que se quer falar.

\section{Nascer na hora do sofrimento}

Refletir sobre os modos com que a dor se constitui nas experiências de vida, e se expressa através da fala, é também refletir sobre como noções de tempo são articuladas às categorias utilizadas para expressar agruras, como é o caso da palavra "sofrimento". Nos casos aqui analisados, o termo é acionado para expressar pesares que surgem em algum momento da vida, gerando marcas profundas sobre indivíduos, famílias, lugares, períodos. É assim que a vivência da dor torna certas pessoas e certos "tempos" "sofridos", outorgando-lhes reputações, qualidades e valores morais que, ainda que não recaiam igualmente sobre todos os membros de uma família ou vizinhança, são socialmente compartilhados e compreendidos.

A palavra "sofrimento" permite movimentar elementos particulares de certas dimensões do vivido que remetem a angústias e dificuldades, provocando novos sentimentos em quem fala e em quem escuta. A emoção da dor pode tanto emergir em determinados pontos da narrativa como imprimir-lhe uma forma, um tom que a sustenta. Este segundo aspecto é evidente no modo com que Joaquina, de 73 anos de idade, elabora sua história de vida. Em uma entrevista gravada em sua residência, Joaquina fala de sua trajetória, tomando o "sofrimento" como referencial central para a construção de seu argumento, de sua visão da própria existência. Transcrevo a seguir as palavras com que ela inicia a narrativa sobre sua vida:

Tudo a gente tem o jeito da vida da gente que a gente traz desde novo. Eu quando era pequena, minha mãe já deu eu pros vizinhos quando eu tinha 4 anos. E eu nesses quatro anos nunca me arregalei na vida. Daí fui indo, fui a ponto que eu cresci, daí eu ia pra aula. E a mulher que me criou saía passear. Ficava até oito dias pra vir na casa. E eu ia na escola sozinha, comia na casa da vizinha. [...]. Daí me davam de comer, e eu ia pra escola. E era desse jeito minha vida. [...]. Minha vida foi, eu nasci na hora do sofrimento. 
Ao considerar o "sofrimento" como propulsor de sua própria história, Joaquina traz uma percepção da dor e da violência como aspectos que permeiam diversos âmbitos da existência. Num primeiro olhar, o "sofrimento" de Joaquina lhe parece não como resultado da ação de alguém, mas como propriedade da hora do seu nascimento, que por isso mesmo a acompanha pelo resto da vida, como destino e horizonte moral. O "sofrimento", do seu ponto de vista, é o atributo de um momento que se torna o tempo cotidiano, em suas palavras, um "jeito" de ser. Através de sua narrativa, ela reflete sobre diversas relações que, ao longo de sua história, trouxeram-lhe angústias e tristezas, dentre as quais aquela com os pais biológicos e com os pais de criação, tal como se apresentam no trecho transcrito.

Segundo Joaquina, sua mãe se separou de seu pai e encontrou um novo marido, que mentiu que ela teria que "dar" todos os seus cinco filhos, ou um juiz de paz lhe tomaria as crianças. Somente a irmã mais velha de Joaquina, já moça, permaneceu com a mãe. Todos os outros filhos foram "extraviados", como ela afirma, entre famílias de Pinhão. Joaquina, então com 4 anos de idade, ficou com um casal que tinha um filho solteiro, já com seus 18 anos de idade, e outro casado, que não morava mais com eles. Os pais adotivos, localmente concebidos como "pais de criação", colocaram-na na posição de serviçal, que tinha que cuidar da limpeza da casa e do trato das galinhas e dos porcos, destino comum às filhas "criadas". Apesar de as filhas biológicas também aprenderem e dividirem com a mãe os serviços domésticos, as crianças "criadas" têm o trabalho como função central nas casas das famílias com que vivem. Sobre esse período de sua vida, Joaquina lembra que "sofria", pois, enquanto criança, "era fraca para o serviço".

Outra reviravolta na vida de Joaquina se deu com o suicídio do filho solteiro do casal que a acolhera. $\mathrm{O}$ rapaz, ainda jovem, tirou a vida para não ser obrigado a casar com uma moça a quem engravidara. Pouco tempo depois da morte do garoto, o pai adotivo de Joaquina veio a falecer, segundo ela "também de nervoso por causa do filho". Ela ficou só com a viúva, que então passou então a frequentar festas e a gastar todo o dinheiro que tinha. Joaquina passava dias sozinha em casa, sem alimento, tendo que comer na vizinha antes de ir para a escola, que começou a cursar aos 10 anos de idade. Surge então uma nova relação em sua vida:

Apareceu um viúvo, eu tinha 12 anos. Ele era viúvo. Queria ficar comigo. [...]. Daí a velha, daquele jeito de sair toda a vida pra lá e pra cá. Foi a ponto que

Horizontes Antropológicos, Porto Alegre, ano 20, n. 42, p. 107-131, jul./dez. 2014 
o sofrimento é o mesmo sofrimento, faz a gente sofrer mais. Daí ele veio na casa da velha e não tinha um nada de comida na casa. Nada, nada, nada... E ele disse: "Mas com que você passa?" Eu disse: "Eu passo com vento." É certo, não tinha nada pra comer. Daí ele ia seguido lá na casa da velha, e vinha, seguidinho na casa da velha. A velha 'tava, ele perguntava. Ele queria que eu ficasse com ele. Que a minha fome não passava. Mais sofrendo que eu 'tava não precisava mais. Daí eu fiquei com ele. Saí da casa da velha e fui pra casa dele. $\mathrm{E}$ a velha ficou sozinha. O que ficou em casa, roupa, essas coisas, a velha não me entregou nada.

Nessa passagem, Joaquina traz uma série de reflexões acerca da sua condição de "sofrimento", e dos caminhos pelos quais essa sorte a conduziu. Em particular, chama atenção a ideia de acúmulo de dor que o sofrer produz, um "sofrimento" que se torna "o mesmo", o cotidiano. Casar com um homem bem mais velho, então, é ingressar em uma nova realidade, onde o que está em questão é mudar de vida, "sair" da "casa da velha" que a adotara.

Aos 13 anos de idade, Joaquina teve seu primeiro bebê, que nasceu morto. Quando ela estava com 35 anos, seu marido faleceu, em virtude de um acidente durante a colheita de erva-mate. Antes disso, porém, os homens da madeireira já haviam tentado convencê-lo a assinar um "contrato" com a empresa, acordo que ele se negou a fazer, apesar das ameaças de despejo. Agora que estava viúva, Joaquina teria de lidar sozinha com esses prenúncios de expulsão das terras em que vivia. Naquela época, seis dos seus oito filhos ainda moravam com ela, e o mais novo tinha pouco mais de um ano de idade. Foi então que mais uma ruptura se deu em sua vida. Certo dia, Joaquina teve de se ausentar de sua casa, para ajudar no parto de uma mulher que morava longe. Por isso, ela levou suas crianças consigo, retornando somente no dia seguinte. Ao voltar, encontrou somente brasas e as cinzas do seu lar. Tudo havia sido queimado.

As queimas de residências são rememoradas por aqueles que viveram o conflito com a Zattar como uma prática comum perpetuada pelos "jagunços", a fim de fazer valer a vontade de seus chefes. Os posseiros temiam deixar suas casas sozinhas, pois sabiam que era possível que elas fossem incendiadas. Houve ainda casos de mulheres que foram forçadamente retiradas de suas moradias e assistiram à sua queima. Ao falar sobre isso, Joaquina argumenta que mesmo sabendo que sua casa foi queimada pelos homens da empresa, ela não poderia prestar queixas do ato:

Horizontes Antropológicos, Porto Alegre, ano 20, n. 42, p. 107-131, jul./dez. 2014 
Eles queriam que eu desse parte, mas parte de quem? Nós não vimos. A senhora veja que a pessoa pra dar parte de uma coisa tem que ter tudo justo, senão o bandido ainda vai pra cima da gente. Então eles diziam que foi o Zattar que mandou queimar. De raiva de mim, que eles não podiam tirar eu dali. E diziam pra mim que foi o Zattar que mandou queimar e pra mim dar parte deles, pra eles pagarem tudo. Mas quem que viu? A senhora já viu o bandido fazer um serviço e levar uma testemunha? Agora quem que vê, quem que ia saber que foi eles, quem que viu? Eu ia dava parte deles, colocavam eles na cadeia e tiravam eles de lá.

Há noções sobre justiça e reparação de danos que são acionadas nesse olhar que Joaquina produz sobre sua condição, tomada como um lugar de onde não se podia produzir uma denúncia, por não haver testemunha da queima da casa, e porque qualquer palavra dita produziria consequências ainda piores, na medida em que o "bandido" poderia passar a persegui-la. Na cadeia de perpetradores da violência, o mandante do "serviço" aparece como sujeito plural, um "eles" cuja síntese é "o Zattar", o qual remete sobretudo aos administradores da empresa e chefes dos "guardas" em Pinhão. Quando falam, por exemplo, de antigos gerentes do complexo madeireiro, os moradores do município costumam associá-los ao sobrenome "Zattar".

Se o mandante dá ordens, existem também aqueles que "fazem o serviço", idealmente concebido como ato impossível de ser testemunhado, já que feito às escuras, longe dos olhos de todos. Contudo, essa é uma elaboração que tem a ver com percepções sobre a atuação da Justiça, e com concepções morais sobre a formulação de acusações e suas possíveis consequências. Quase sempre se sabe quem foi o responsável e o executor de certas violências. No entanto, expressar isso publicamente, levando o conflito a juízo ou tornando-o matéria de conhecimento social, é mover a situação adiante, estendendo-a a novos níveis de ameaças e violências. É comum a expectativa de que "vinganças", como formas de retaliação de certas ações de agressão, sejam planejadas e executadas por indivíduos e suas famílias. Mas nem todos dispõem de meios ou possuem a vontade de tomar esse tipo de atitude.

Nas condições em que se encontrava, Joaquina teve de recorrer às "autoridades" da localidade onde ela vivia, que na verdade eram inspetores de quarteirão e chefes de família tradicionalmente encarregados de solucionar conflitos e disputas no interior do município. Reuniram-se oito homens, aos quais ela pediu que fizessem um rancho para que ela pudesse ficar com suas crianças:

Horizontes Antropológicos, Porto Alegre, ano 20, n. 42, p. 107-131, jul./dez. 2014 
"Façam um rancho pra mim ficar com as crianças, pra mim deixar as crianças no rancho pra mim trabalhar, pra dar de comer meus filhos, comprar o que eu preciso, agora que eu não tenho nada." Daí que eles acharam que era melhor eu dar tudo as crianças. "Então a senhora dê tudo as crianças, que a senhora é nova. Tem só 35 anos, a senhora pode trabalhar pra senhora viver, e as crianças a senhora dê tudo." A senhora já viu pra uma mãe, dar tudo meus filhos? Daí falei pro senhorio: "Não senhor, eu quero muito bem meus filhos, não posso extraviar meus filhos, não tem jeito. Eu sofro, mas nem que eu trabalhe o dia inteiro, que eu ganhe um pacote de sal e beba uma salmoura com meus filhos de tarde embaixo de uma árvore, não dou nenhum.” Que a mãe mesmo que quer bem a família não extravia nenhum. [...]. Então tinha jeito? Morreu o marido, queimaram minha casa e ainda dar os filhos? Então me matem de uma vez! "Me matem de uma vez! Tem oito homens aí, não tem uma faca? Eu vou ali, tem um vizinho pra lá do Nhô Jovenal, eu vou lá e peço uma faca, vocês me atorem o pescoço! Mas atorem rentinho, que enquanto não pular uma veia vocês não tomam meus filhos!" [...]. E daí não quiseram me matar. E Deus que me perdoe, numa hora daquelas se eles me matassem eu não sentia a morte! Porque eu 'tava enterrada. Não tinha mais o que fazer! Não tinha mais!

Essa passagem concentra várias das agressões vividas por Joaquina no contexto de relacionamentos em que ela se encontrava. Dentre as diversas ausências que aqui compõem seu sofrer, as mais destacadas são a ausência de solidariedade, de "querer bem", e a de voz, de possibilidade de falar e de obter ajuda. Os parentes do marido morto lhe sugerem a possibilidade de doar seus filhos, atitude semelhante a que teve sua mãe biológica e que a levou ao "sofrimento" junto aos pais de criação. As "autoridades", homens da comunidade, aparecem como figuras surdas, incapazes de ouvir Joaquina e de oferecer-lhe ajuda. Ao contrário, eles a condenam a abrir mão dos filhos, ao desejo de morrer. Através de seu relato, Joaquina conecta as agressões que se deram ao longo da luta por terras a outras relações, que no caso aqui exposto são aquelas entre gêneros, parentes, vizinhos e "autoridades" tradicionais ou institucionais. Assim, testemunhar, expor seu "sofrimento", é também submeter-se ao poder que as pessoas exercem umas sobre as outras, o que leva ao risco de perder, de se envergonhar, de ser publicamente exposta.

Por fim, o filho mais velho do primeiro casamento do falecido marido de Joaquina decidiu ajudá-la. Ela ficou por um tempo na casa dele e depois conseguiu madeira para fazer uma pequena casa. A fim de sustentar sua família, ela trabalhou muito e por muitos anos no extrativismo de erva-mate em terras

Horizontes Antropológicos, Porto Alegre, ano 20, n. 42, p. 107-131, jul./dez. 2014 
alheias. Foi um dos seus contratantes que lhe deu um terreno, o qual não tinha documentos e era visado por agentes ligados à madeireira. Novamente, os homens de armas da empresa, que então dominava grande parte das áreas ao redor do lote de Joaquina, procuraram-lhe para que assinasse um "contrato". Ela não aceitou. Chegou a passar por um processo na Justiça por retirar erva-mate das terras que a empresa reclamava para si, saindo vitoriosa. Em meados dos anos 1990, Joaquina entrou com o pedido de usucapião do terreno em que vivia, e assim obteve a propriedade de suas terras.

Em suma, Joaquina compreende os eventos trágicos que lhe ocorreram no contexto do embate com a Zattar como inseridos num horizonte de "sofrimento" que permeia sua existência. Sua dor ultrapassa as situações pontuais de angústia que ela cita em seu relato, mas encadeia todas elas, de modo que o sentido do "sofrimento" encontra-se na própria existência, no estar viva. Assim, a queima de sua casa, apesar de destacada como um momento específico de angústia, é qualificada por Joaquina a partir de um quadro mais amplo de compreensão de sua trajetória e do contexto de relações em que se insere e se percebe.

\section{Quando a desgraça vem}

Se o "sofrimento" pode ser encarado como um destino, ele também pode ser referido a um "tempo" específico, enquanto sucessão de eventos. Nas histórias de Francisca, senhora de 60 anos, sofrer tem a ver com trabalho excessivo e privação, e diz respeito ao período em que a madeireira era bastante ativa em Pinhão, concebido como o “tempo do Zattar”. Viúva de um funcionário da firma, o qual se tornou um homem de armas a convite dos próprios administradores da empresa, Francisca sempre chama seu falecido marido, Leonardo, de "guarda", termo que indica respeito e um abrandamento do lado mais violento de sua profissão. Há desconfianças de que ele foi morto a mando de colegas de trabalho, por razões que permanecem obscuras para ela.

Nos relatos de Francisca e de Elena, sua filha mais velha, o "tempo do Zattar" é tratado como "sofrimento", e rememorado como uma época de "pobreza", "escravidão", e perda do território para muitas pessoas. Esse "tempo" aproxima-se da noção de "tempo da política" discutida por Palmeira (2002), onde o que importa não é tanto uma noção cumulativa ou linear de tempo, mas um modo de se "recortar/representar a estrutura social" e de escrever atividades e comportamentos adequados a determinado momento (Palmeira, 2002, p. 172).

Horizontes Antropológicos, Porto Alegre, ano 20, n. 42, p. 107-131, jul./dez. 2014 
Enquanto ressaltam as dificuldades do "tempo do Zattar", Francisca e Elena produzem críticas sobre a situação que viviam e sua postura diante dela. "A gente não pensava que aquilo tudo poderia ser diferente", diziam elas, lembrando dos seus pés descalços sobre as grandes geadas do inverno, das suas roupas que não eram suficientes para protegê-las do frio, e do fogo, feito no chão, que as esquentava nesses dias gelados. É comum, na zona rural de Pinhão, que as pessoas que falem do passado salientem o frio, as vestimentas precárias e as pessoas em volta do fogo. Nos relatos de Elena e Francisca, porém, essas dificuldades são vinculadas a relações que são percebidas como parte de um "tempo", o "do Zattar". Falar desse "tempo", então, não é somente construir compreensões sobre o passado, mas também olhar para o presente e para as expectativas de futuro, o que implica reflexões sobre o atual contexto de vínculos com a empresa e com a terra em que se vive.

Elena e Francisca contam que faziam parte de um "povo oprimido", e que na medida em que dependiam "do Zattar", viviam com medo dele. A madeireira possuía cinco portões ao longo da estrada rural em que se localizava, obrigando as pessoas que moravam na região ou que por lá passavam a pedirem permissão para transitarem no interior desse território. Toda a erva-mate que a família de Francisca tirava, todo o seu trabalho, em seus próprios termos, "era do Zattar". Além disso, a empresa operava com uma moeda própria, chamada boró (Monteiro, 2008, p. 39), que consistia num papelão marcado com um valor, o qual era pago aos trabalhadores da empresa, que por sua vez eram obrigados a gastá-lo nos armazéns da própria Zattarlândia. Esse dinheiro é considerado o principal símbolo desse sistema de "escravidão" vivido pelos funcionários da firma.

A madeireira também exercia grande influência sobre a política local, sendo que seu gerente, Osiris Roriz, foi o primeiro prefeito do município, emancipado em 1964. Segundo Francisca e Elena, só se elegiam prefeitos e vereadores que fossem "do lado do Zattar", cujos gerentes "mandavam" as pessoas votarem em seus candidatos.

As narrativas do "sofrimento" de Elena e Francisca esclarecem uma postura política que envolve julgamentos sobre a estrutura socioeconômica da firma e suas ações em Pinhão, e não, como no caso de Joaquina, uma visão mais ampla de existência. O "sofrimento", assim, recebe diferentes ênfases e tons, e recai sobre diferentes questões, tendo em vista a pessoa que 
conta sua história e o contexto de sua narrativa. O passado pode ainda ser visto de modo idealizado, como quando é tido como época em que o "respeito" e a "palavra" imperavam entre as pessoas. O próprio "tempo do Zattar", quando observado do ponto de vista daqueles que não tiveram problemas de terras com a madeireira, é muitas vezes considerado como um período que trouxe riquezas e desenvolvimento a Pinhão e àqueles que trabalharam para a empresa.

Leonardo, marido de Francisca, foi morto no início dos anos 1990, momento em que o conflito de terras atingia seu auge. Ao falar da profissão do falecido, a senhora afirma que ele "não gostava" daquilo que fazia, queria apenas ganhar o seu dinheiro para alimentar seus filhos, e não faria mal a ninguém. Desse modo, Francisca busca diferenciar o marido dos "jagunços ruins", aqueles que estavam na profissão porque teriam satisfação em causar malefícios aos outros. Francisca recorda que um mês antes de morrer, seu marido orientou-a a ficar nas terras caso alguma coisa acontecesse com ele. Ele foi morto na ocasião de uma corrida de cavalos, por um homem que não era funcionário da empresa, mas que tinha fama de matador. Quando Elena e seu marido foram avisar Francisca sobre o ocorrido, tiveram seu veículo alvejado por tiros, disparados, segundo elas, por "jagunços bêbados". O marido e o cunhado de Elena, que também estava no carro, foram atingidos e tiveram de ser hospitalizados.

A minha sogra que dizia: “A desgraça quando vem traz até os netos." Que é certo, né? Você veja, tudo numa pancada só. Não sei como a gente aguenta tudo, né?

Essas palavras de Francisca trazem novamente a questão da relação entre sofrimento e tempo, através de um ditado segundo o qual a "desgraça” é algo que "vem", portanto, que se movimenta e que se estabelece na vida, muitas vezes de modo definitivo. Para Francisca, Leonardo foi morto porque sabia de alguma coisa que comprometia outros sujeitos. Talvez tivesse visto algo comprometedor, ou tivesse se recusado a participar de algum esquema em que os seus colegas tivessem envolvidos, possivelmente o roubo da erva-mate dos terrenos sob domínio da Zattar, ou o assassinato de "moradores".

Que a gente sabe, assim, a gente tinha desconfiança de muita coisa, que eles não contavam nada também. O meu marido trabalhava com eles, e o meu marido 
nunca falou nada, assim, de violência que ele visse eles fazerem, nada. [...]. E daí de um ponto em diante, sabe, eles levavam, ele ficava até 15 dias assim, nas áreas, aqueles assentamentos [...]. Que tinha uns sem-terra lá, foi em 90 e parece que. Acho que foi em 89 pra 90. Oitenta e nove. Que daí eles ficaram acho que uns dois anos lá, atendendo aqueles sem-terra lá, e ele tirando madeira e os sem-terra lá. Ele ficava até um mês longe de casa. Depois já nem vinha. O prefeito era o Darci Brolini, né, e a gente escutava no rádio aquela barbaridade, que diz que davam muito tiro nos sem-terra, faziam muita violência assim. Daí o Darci Brolini foi e retirou os sem-terra de lá. Pegou e tirou, não sei pra onde é que ele levou. Daí eles pararam com aqueles serviços lá, dali a um mês mataram ele. O meu marido.

Leonardo, portanto, passava períodos fazendo seu trabalho nos assentamentos, onde Francisca ouvia, pelo rádio, que acontecia "muita violência". Esses "sem-terra" que aparecem no relato não possuem relação com o MST, mas são pessoas que participaram da reocupação de certos terrenos que estavam sob o domínio da madeireira, os quais posteriormente se tornaram assentamentos regularizados pelo Incra. Nessas áreas, os homens da empresa reprimiam a extração de material vegetal, e pressionavam a população para que saíssem de lá. Numa dessas incursões dos "jagunços”, eles realizaram um tiroteio contra uma escola rural em pleno horário de aulas, ferindo uma criança.

Muito do que aconteceu nesses lugares é silenciado. É assim que a filha de um antigo "guarda" da madeireira, que não mora mais em Pinhão, disse-me que só recentemente, depois que teve um câncer, que seu pai começou a falar das atrocidades que alguns de seus colegas cometiam para com os "sem-terra". Ele lembrou de uma vez em que um dos homens de armas que estava com ele atirou pelas costas em uma criança, que carregava um balde de água. É nesse sentido de ultrapassagem de limites do que é aceitável em uma situação de conflito armado que Francisca usa o termo "violência" em seu relato, condenando moralmente as ações dos homens de armas da madeireira.

Por medo do homem que matou o seu marido, Francisca não fez nenhuma queixa contra ele:

Mas eu pra falar bem a verdade eu não conheci esse homem, só ouvi falar! Daí eu já tinha um medo depois que ele matou o falecido. Eu tinha medo que ele fizesse alguma coisa pra nós. Mas daí ele foi embora, e eu fazia um plano pra mim: "Mas meu Deus do céu, que Deus desterre esse homem pra bem longe pra ele não vir incomodar mais.” [...] Eu já tinha um medo, meu Divino de Deus! 
Eu saía assim, se algum pica-pau falava eu achava que era o homem. Eu não conhecia, eu nunca tinha visto o homem, não sabia de que jeito que era, um me contava que era de um jeito, outro me contava que era de outro. A gente ficava assim, até no ônibus, né, dá medo de a gente ver. Daí um dia eu pensei: "Mas já que eu não conheço ele, ele também não vai me conhecer." [...] Uma vez minha sogra disse: "Seja boba, comadre! Quem faz essas coisas vai embora pra bem longe e nunca mais incomoda!" Ele já tinha ido mesmo embora.

O homem que matou Leonardo se mudou para outro município e, anos depois, foi alvejado em um ponto de ônibus, em "vingança" por ter matado um comerciante local. Mas isso não acalmou Francisca. Seis anos após a morte de seu marido, os homens de armas da empresa passaram a ter interesse em tirá-la do seu terreno, a fim de estabelecer parentes deles naquela área. Numa madrugada, eles atiraram contra sua casa, direcionando as balas contra o telhado, a fim de assustá-la e suas crianças. Francisca recolheu as balas que ficaram em volta de sua casa, e foi à delegacia para registrar queixa do tiroteio. A princípio, o delegado se negou a atender o pedido. Segundo ela, ele afirmava que como não sabiam quem havia atirado, seria difícil resolver aquela situação. Ela teve que insistir para conseguir registrar a ocorrência.

Depois disso, os funcionários da empresa tentaram fazer um acordo com Francisca, propondo-lhe que fosse morar em uma outra área. Um dos homens da firma chegou a oferecer-lhe uma casa na zona urbana de Pinhão. Mas Francisca ficou, e teve de enfrentar diversas "perseguições". Eles destruíam suas cercas, passavam por dentro do seu terreno, tomavam sua erva-mate e seu pinhão, que vendiam, dividindo o dinheiro entre eles mesmos.

As coisas mudaram para Francisca depois de 1996, quando o Incra mediu seu terreno e ela começou a pagar o Imposto Sobre a Propriedade Territorial Rural (ITR). Nessa época ela se envolveu com os órgãos e advogados de defesa dos posseiros, e teve de enfrentar, após ter entrado com pedido de usucapião sobre as terras em que vivia, um processo de reintegração de posse. A empresa perdeu a causa e, em 2013, Francisca obteve sua usucapião.

Essa história exemplifica como, nesse conflito de terras, pessoas de algum modo vinculadas à empresa poderiam se tornar posseiras e ingressar na luta por direitos territoriais. É assim que essa luta não compreende um quadro de conflito cujos lados são bem definidos. Os sujeitos transitam entre a proximidade e o afastamento da madeireira e de agentes ligados a ela, constituindo-se também a partir das relações que possuem com a firma e seus funcionários. 
Essas ligações não são frutos de estratégias ou de escolhas, mas são vividas como parte da experiência cotidiana e dos feixes de vínculos que configuram aquela localidade. Nesse sentido, através das narrativas das pessoas que participam dele, o conflito emerge como objeto em disputa, assumindo diferentes sentidos e termos para os grupos que nele tomam parte, os quais o concebem a partir de referências distintas (Figurelli, 2011).

Os casos de Francisca e de Joaquina apontam para as ligações entre silêncio e testemunho, e para como a busca pela reparação de agressões envolve um alguém para se acusar, um alguém que pode ser uma ameaça ainda maior quando os conflitos chegam às mãos das autoridades policiais. Ao reconhecermos que o conflito suscita participações, e constrói um campo de comunicação onde há o compartilhamento de certos códigos e noções (Marques; Comerford; Chaves, 2007), precisamos levar a sério as escolhas que as pessoas fazem de deixar de falar, e considerar esses silêncios como parte de um repertório de práticas e concepções que existem sobre ações e reações em situações de agressão.

A constituição dos conflitos e os processos que os formam são inseparáveis de sua dimensão narrativa, de forma que existem relações entre a lógica que estrutura o contar histórias e a lógica das ações dos sujeitos que possuem desavenças entre si (Comerford, 2003). Observando a ênfase que as narrativas aqui analisadas dão a acusações na terceira pessoa do plural, e pensando nessa forma de culpabilização em relação aos modos como se deve proceder em momentos de embate - o que dizer, como dizer, aonde ir e aonde não ir, como interagir com o inimigo - percebemos que falar é também envolver-se com o perigo em outros níveis. Dar voz a situações e nomes a agressores implica reconhecê-los publicamente, assumindo os riscos de enfrentar o acusado e a comunidade onde se vive, cujos membros também promovem julgamentos sobre o caso em questão, tornando a pessoa que viveu experiências disruptivas em objeto de avaliação nas conversas sobre o assunto.

$\mathrm{O}$ que o silêncio permite compreender nessas falas sobre situações de violência é que o próprio conhecimento de certos eventos e pessoas é uma ameaça. Mesmo que não resulte em um atentado concreto à vida, esse conhecimento pode colocar em risco relações, na medida em que as pessoas constantemente reelaboram seus pensamentos e atitudes frente as outras a partir das maneiras com que se percebem. Desse modo, os silêncios também têm a ver com a "pequena política" (Bailey, 1971) da vida cotidiana, aquela que diz 
respeito a reputações e ao jogo entre a manutenção da individualidade e a ação guiada pelos interesses de uma comunidade mais ampla.

Se saber de algo pode significar assumir compromissos a respeito de acontecimentos e pessoas, então o que esses silêncios demonstram é também a existência de códigos sobre o que e como se falar da violência. Assim, não é por não refletirem sobre as diversas agressões que vivenciam, ou por se esquecerem delas, que as pessoas as silenciam. Ao contrário, é justamente a reflexão e o interesse em manter discrição que produzem essas ausências nas falas. Esses silêncios expressam as tensões que permeiam a vida dos sujeitos, os modos com que resolvem suas angústias e como as comunicam.

\section{Morreu muita gente...}

Quando rememoram o "tempo" em que os "guardas", "jagunços" e "pistoleiros" os ameaçavam, os posseiros costumam dizer que naquela época "morreu muita gente", referindo-se aos assassinatos ocorridos ao longo do conflito de terras. Esse é um ponto de vista que não se limita àqueles que lutaram contra a madeireira, mas é compartilhado por vários moradores do município, independentemente de seu status ou de viverem na zona rural ou urbana. A expressão "foi feio" é recorrente nas falas sobre o lado conflituoso da história da exploração madeireira em Pinhão. Vem acompanhada de comentários sobre a quantidade de mortes, e sobre episódios em que "jagunços" jogavam pessoas de caminhões em movimento, ou as matavam publicamente em estradas, bares, festas. Tocaias, "provocações" e perseguições realizadas pelos homens de armas ligados à madeireira são temas mencionados a fim de afirmar, nas narrativas, o sentimento de tensão que era vivido por aqueles que tinham que conviver com a presença dos agentes da empresa.

Essas mortes, entretanto, são pouco esmiuçadas nas narrativas. A ênfase dos sujeitos que falam sobre elas não é direcionada a como as coisas aconteceram, mas sim ao próprio acontecimento e aos seus desencadeamentos, sempre acompanhados de julgamentos morais e de um tom de voz que convida os ouvintes a compartilhar desses sentimentos. Assim, a expressão "morreu muita gente" consiste numa afirmação envolvida em muitos silêncios, pois não se fala dos mortos em particular e nem dos pormenores da situação que os levou a tal destino. 
Ocorreu certa vez de um senhor idoso, proprietário de terras, morador de uma comunidade vizinha à antiga Zattarlândia, dizer-me que no "tempo do Zattar" tudo era "muito bom" e "muito bonito" e que ele não falaria que aconteceu de "ruim" por lá, porque poderia "se complicar". O temor das atrocidades desse período, portanto, permanece no cotidiano dos sujeitos, influindo não só sobre suas falas, mas sobre a própria experiência de vida.

Há, porém, histórias que são relembradas como emblemáticas da crueldade de certos homens de armas e da madeireira. É o caso da morte de Janaína, criança de um ano de idade que morreu em um incêndio provocado contra o paiol de sua família, no início dos anos 1990. Os pais da menina haviam participado de uma reocupação de terras da empresa, a qual fora promovida pelo Movimento de Posseiros como estratégia de enfrentamento. Certo dia, a família de Janaína foi trabalhar na lavoura em volta do paiol e deixou a criança dormindo dentro dele. No momento em que perceberam o fogo, ele já estava alto. Os homens da empresa haviam passado por ali e incendiado o paiol, que acreditavam estar vazio.

A história da criança é enfatizada na região do município onde ela viveu como exemplar daquilo que os homens a serviço da empresa eram capazes de fazer. Mesmo que em algumas vezes as narrativas sobre Janaína venham acompanhadas da indicação de que os "guardas" não sabiam que havia uma criança dentro do paiol e, portanto, não tinham a intenção de matá-la, ressalta-se sempre os riscos que as ações desses homens impunham sobre as comunidades rurais, devido à sua própria crueldade de realizar esse tipo de perseguição, tocando fogo nas casas alheias.

Há ainda outras histórias de morte das quais se fala abertamente. Enquanto mexem com o inesperado e invocam ideais de justiça dos próprios posseiros, essas mortes são publicizadas, e afirmam a força daqueles que seriam idealmente concebidos como mais "fracos" numa situação de conflito. Essas histórias de morte são aquelas que envolvem "jagunços" memoráveis, cuja fama de "valentes" e "ruins" era difundida a ponto de, da perspectiva das pessoas que contam essas histórias, os próprios homens de armas em questão parecerem duvidar de que alguém poderia lhes ferir. A valentia em questão não é necessariamente algo positivo. Embora em alguns momentos ser "valente" possa significar ser corajoso, esse adjetivo é majoritariamente utilizado para falar daqueles homens que lançam mão da força e de armas para brigarem sempre que possível. Assim, o "valente" é aquele que não pondera 
quando é preciso brigar ou não. Por isso, ele também pode ser tido como um "covarde", um "sem-vergonha", um "prevalecido", já que pode atacar qualquer um, inclusive pessoas consideradas mais vulneráveis que ele, como mulheres e crianças.

Pedrão e Serjão, como eram conhecidos os "jagunços" em questão, são exemplares do ditado segundo o qual "o mais prevalecido morre pela mão do mais fraco". Essa máxima ilustra concepções morais sobre como atitudes de soberba e arrogância diante da fraqueza do outro podem levar aquele que se acha mais forte à ruína. Enquanto Pedrão foi morto por um menino, o qual havia visto o "jagunço" matar seu pai, Serjão foi morto por uma mulher da qual era padrinho de casamento, após ter proferido uma série de ameaças contra ela e seu marido, e ter matado um jovem rapaz que também era seu afilhado, pelo fato de ele estar trabalhando na lavoura sem permissão do "jagunço".

Quando narradas por mulheres, as mortes desses homens de armas são acompanhadas de comentários como "bem feito pra eles!", ressaltando o desdém que ambos tinham para com os posseiros, e falas como "Deus que me perdoe, mas quem matou esse homem fez um favor pra nós!", destacando assim o quanto eles destratavam e incomodavam as pessoas. Além disso, as narrativas sobre esses episódios invocam a ambiguidade desses "valentes", tratando-os muitas vezes como bêbados que só agiam com bravura quando estavam acompanhados, e caçoando dos seus gestuais, vozes e tipos físicos.

Por que, então, falar dessas mortes é possível, enquanto outras permanecem silenciadas sob a reticente expressão "morreu muita gente..."? Chamar um ato ou alguém de "violento" é também reprová-lo moralmente e, enquanto a punição parece um contraponto justo à violação da integridade e do bem-estar, surgem questionamentos acerca das articulações entre certos usos da violência e o fazer justiça, enfim, sobre que atos envolvendo o uso de força para ferir alguém são negativos e condenáveis, e que atos são tidos como positivos e necessários (Fassin, 2012, p. 13). Enquanto fenômeno relacional, a violência não é algo que se define a priori, mas que se configura segundo termos sociais, sobretudo a partir da representação que se tem da vítima e do agressor (Sarti; Barbosa; Suarez, 2006, p. 169). Como as mortes dos “jagunços" envolvem uma inversão de forças, onde as armas que matam estão nas mãos dos supostamente mais "fracos", elas não representam ações de vitimização, mas sim de reparação, de fazer justiça com as próprias mãos, de dar cabo do agressor.

Horizontes Antropológicos, Porto Alegre, ano 20, n. 42, p. 107-131, jul./dez. 2014 
Ao trabalhar com as representações heroicas elaboradas na Odisseia, Vernant (1996) argumenta que nem todos os sujeitos que participam de certos episódios serão rememorados individualmente, e que, no caso em questão, é a morte heroica que assegura a permanência do nome e do renome de certos personagens. Assim, a morte e a maneira com que se morre são centrais para a fixação do indivíduo na memória coletiva. A morte, portanto, é matéria de interesse dos vivos, é a eles que cabe rememorar e definir o que é uma morte heroica. Podemos pensar então em como as mortes ocorridas no conflito de terras em Pinhão são passíveis de uma classificação que envolve também visões sobre pessoas e ações. Se as violentas mortes de posseiros são anunciadas mas não são descritas, as mortes dos "jagunços", tal como contadas pelos posseiros, são eventos emblemáticos. Suas narrativas falam do heroísmo dos seus protagonistas que, "mais fracos" que seus inimigos, foram capazes de dar fim neles de uma maneira que, enquanto desejada por muitos, era também inesperada.

\section{Consideracões finais}

As narrativas sobre "sofrimento" e sobre as mortes ocorridas no conflito em Pinhão me inspiraram a questionar como, nas narrativas sobre o passado, o silêncio nos fala da violência que marca as trajetórias das pessoas na luta por terras. Através dos casos aqui analisados, a violência aparece não somente nas agressões pontuais, nos assassinatos de que não se fala porque não se compreende, nas mortes publicizadas a fim de enfatizar a crueldade dos "jagunços" ou a capacidade dos posseiros de fazerem sua própria justiça. A violência perpassa e constitui relações e territórios, e na medida em que destrói e ultrapassa limites morais, ela também cria o mundo social. Porém, dizer sobre ela é mexer com todos os constrangimentos e relações que envolvem as pessoas que vivem nesse contexto, pois falar sobre o conflito implica, em certa medida, agir sobre ele.

Assim, os silêncios aqui discutidos aludem a modos de ação em situações de embate e inimizade, fronteiras das possibilidades de fala e, finalmente, a possibilidades de denúncia das agressões vividas. Nos relatos de Joaquina e de Francisca, há a alusão ao que seria uma denúncia aceitável: aquela em que o agressor é reconhecido e há provas contra ele. É isso que faz 
com que Joaquina recue em procurar a reparação à queima de sua casa, e Francisca ouça do delegado que sua denúncia não será investigada. Essas mulheres estão falando, portanto, da impossibilidade de seus testemunhos serem ouvidos e de que alguma justiça seja feita em seus casos. Além disso, há outros elementos que entram em jogo no ato de falar e de denunciar uma agressão sofrida, como a própria reputação da pessoa que sofreu a violência. Ou seja, não é somente a sentença do juiz que aí é considerada, mas sim uma série de sentenças que serão produzidas pelos agressores e por outros membros da comunidade.

Ao analisar as memórias dos moradores da sede urbana de Pinhão, e dos moradores das áreas de faxinais, Porto (2013a, p. 245) argumenta que o passado do qual se quer falar é aquele que se refere ao modo de vida dos antigos, que viviam relativamente isolados e consumiam aquilo que era produzido localmente pelos próprios trabalhadores rurais, cujo trabalho também era visto como "sofrido". As lembranças da violência ocorridas ao longo do conflito com a Zattar, entretanto, é que são "sofridas", difíceis de serem narradas, e perigosas, por poderem despertar sentimentos de revolta e de "vingança" no momento presente. Carregado de significados, e produtor de sentidos, o "tempo" é algo através do qual falamos e definimos relações (Fabian, 1983, 1998). Considerando esses olhares sobre o passado, e os casos aqui analisados, é possível observar que os próprios sentimentos que emergem da violência, ou que produzem atos de violência, são apresentados segundo perspectivas de temporalidade, do mesmo modo com que produzem concepções de "tempo", enquanto referencial para certas associações entre pessoas, relações de poder, eventos, sentimentos e histórias.

Para aqueles que vivem o conflito de terras, dar voz às agressões vividas é também arriscar-se. É trazer à tona sentimentos que podem reacender o conflito e dar lugar a novos atos de violência. É levar a público sua condição, abrindo chances de julgamento sobre sua pessoa, seu caráter, sua intimidade. Não há como fazê-lo sem se sujeitar à possibilidade de novas angústias. Ainda mais porque o "quem" responsável por essas ações, enquanto um "eles" sobre o qual não se tem provas, refere-se a uma rede de expropriação cujos agentes, além de muito bem conhecidos, fazem parte das famílias e das vizinhanças que ameaçam. 


\section{Referências}

AYOUB, D. Madeira sem lei: jagunços, posseiros e madeireiros em um conflito fundiário no interior do Paraná. Dissertação (Mestrado em Antropologia Social)-Setor de Ciências Humanas, Letras e Artes, Universidade Federal do Paraná, Curitiba, 2011.

AYOUB, D. Os posseiros do Pinhão - conflitos e resistências frente à indústria madeireira. In: PORTO, L.; SALLES, J. de O.; MARQUES, S. M. dos S. (Org.). Memórias dos povos do campo no Paraná - Centro-Sul. Curitiba: ITCG, 2013. p. 151-172.

BAILEY, F. G. Gifts and poison. In: BAYLEY, F. G. Gifts and poison. Oxford: Basil Blackwell, 1971. p. 1-25.

CAMPBELL, J. K. A honra e o Diabo. In: PERISTIANY, J. G. Honra e vergonha: valores das sociedades mediterrânicas. Lisboa: Fundação Calouste Gulbenkian, 1971. p. 111-137.

CHANG, M. Y. Sistema faxinal: uma forma de organização camponesa em desagregação no centro-sul do Paraná. Londrina: IAPAR, 1988.

COMERFORD, J. Como uma família: sociabilidade, territórios de parentesco e sindicalismo rural. Rio de Janeiro: Relume-Dumará, 2003.

DAS, V. Life and words: violence and the descent into the ordinary. Berkeley: University of California Press, 2007.

FABIAN, J. Time and the other: how anthr opology makes its object. New York: Columbia University Press, 1983.

FABIAN, J. Moments of freedom: anthropology and popular culture. Charlottesville: University Press of Virginia, 1998.

FASSIN, D. Introduction: towards a critical moral anthropology. In: FASSIN, D. A companion to moral anthropology. Oxford: Wiley-Blackwell, 2012. p. 1-17. 
FIGURELLI, M. F. Família, escravidão luta: histórias contadas de uma antiga fazenda. Tese (Doutorado em Antropologia Social)-Museu Nacional, Universidade Federal do Rio De Janeiro, Rio de Janeiro, 2011.

FOUCAULT, M. História da sexualidade 2: o uso dos prazeres. São Paulo: Graal, 2010.

LAMBEK, M. The past imperfect: remembering as moral practice. In: ANTZE, P.; LAMBEK, M. Tense past: cultural essays in trauma and memory. London: Routledge, 1996. p. 235-254.

LUTZ, C.; ABU-LUGHOD, L. Introduction: emotion, discourse and the politics of everyday life. In: LUTZ, C.; ABU-LUGHOD, L. (Ed.). Language and the politics of emotion. Cambridge: Cambridge University Press, 1990. p. 1-23.

MARQUES, A. C.; COMERFORD, J.; CHAVES, C. Traições, intrigas, fofocas, vinganças: notas para uma abordagem etnográfica do conflito. In: MARQUES, A. C. (Org.). Conflito, política e relações pessoais. Campinas: Pontes Editores, 2007. p. 27-55.

MONTEIRO, N. Madeira de lei: uma crônica da vida e obra de Miguel Zattar. Curitiba, 2008.

PALMEIRA, M. Política e tempo: nota exploratória. In: PEIRANO, M. (Org.). $O$ dito e o feito: ensaio de antropologia dos rituais. Rio de Janeiro: RelumeDumará: Núcleo de Antropologia da Política/UFRJ, 2002. p. 171-177.

PARANÁ. Lei $n^{\circ} 15.673$, de 13 de novembro de 2007. Dispõe que o Estado do Paraná reconhece os Faxinais e sua territorialidade, conforme especifica. Curitiba, 2007. Disponível em: <http://www.direito.mppr.mp.br/arquivos/ File/LEI_FAXINAIS_15673_2007.pdf $>$. Acesso em: 30 dez. 2013.

POLLAK, M. Memória, esquecimento, silêncio. Estudos Históricos, Rio de Janeiro, v. 2, n. 3, p. 3-15, 1989.

POLLAK, M. L’Expérience concentrationnaire: essai sur le maintien de l'identité sociale. Paris: Métailié, 1990. 
PORTELLI, A. The death of Luigi Trastulli and other stories: form and meaning in oral history. New York: State University of New York, 1991.

PORTO, L. Memórias de um mundo rústico: narrativas e silêncios sobre o passado em Pinhão/PR. In: PORTO, L.; SALLES, J. de O.; MARQUES, S. M. dos S. (Org.). Memórias dos povos do campo no Paraná - Centro-Sul. Curitiba: ITCG, 2013a. p. 173-248.

PORTO, L. Uma reflexão sobre os faxinais: meio-ambiente, sistema produtivo, identidades políticas, formas tradicionais de ser e de viver. In: PORTO, L.; SALLES, J. de O.; MARQUES, S. M. dos S. (Org.). Memórias dos povos do campo no Paraná - Centro-Sul. Curitiba: ITCG, 2013b. p. 59-77.

SARTI, C. A.; BARBOSA, R. M.; SUAREZ, M. M. Violência e gênero: vítimas demarcadas. Physis: Revista de Saúde Coletiva, Rio de Janeiro, v. 16, n. 2, p. 167-183, 2006.

SOUZA, R. M. de. "Na luta pela terra, nascemos faxinalenses": uma reinterpretação do campo intelectual de debates sobre os faxinais. Tese (Doutorado em Sociologia)-Setor de Ciências Humanas, Letras e Artes, Universidade Federal do Paraná, Curitiba, 2010.

VERNANT, J. P. L'Individu, la mort, l'amour: soi-même et l'autre en Grèce Ancienne. Paris: Gallimard, 1996. 